\title{
PERANAN PENYIDIKAN PEGAWAI NEGERI SIPIL BERDASARKAN KETETAPAN HUKUM
}

\author{
Welby Ilham Muwaffaq $^{(1)}$, M. Zuhdi Syahputra ${ }^{(2)}$, Yosua Goklas Sitorus ${ }^{(3)}$ \\ 1,2,3 Politeknik Imigrasi Badan Pengembangan Sumber Daya Manusia Hukum dan HAM RI. Indonesia \\ Email : Welbyilham2@gmail.com ${ }^{(1)}$, apacino448@ gmail.com ${ }^{(2)}$,ygoklas@yahoo.com ${ }^{(3)}$
}

\begin{abstract}
ABSTRAK
globalisasi memicu segala aspek kehidupan terutama sumber informasi, iklim, kekayaan alam, teknologi, serta tingkat kemampuan setiap negara menyebabkan ada keterkaitan antar negara yang menjadikan negara saling membutuhkan satu sama lain. Dengan adanya sebuah jalinan antar negara maka terbentuklah sebuah organisasi yang memacu setiap negara untuk berperan aktif dalam pergaulan antar bangsa yang memiliki sebuah tujuan untuk mendapatkan benefit agar menjadi negara maju dan tidak terisolasi.Dengan kekayaan alam yang ada di Indonesia, lokasi yang strategis, Indonesia berusaha untuk menarik wisatawan sebanyak mungkin, serta berupaya juga menjadikan sector pariwisata menjadi salah satu pemasok yang dapat menghimpun pendapatan negara atau devisa pada negara ini. Tujuan tersebut menjadikan pemerintah mengeluarkan kebijakan yang tuntutan pembangunan dapat membuat trjadinya peningkatan arus lalu lintas manusia dari dalam serta ke luar wilayah negara Indonesia sehingga dari pihak pemerintah membuat sebuah ketetapan berdasarkan tugasnya yang diberikan pada pihak keimigrasian untuk pengawasan dan penindakan kepada orang asing yang keluar dan masuk wilayah Indonesia
\end{abstract}

Kata Kunci: Globalisasi, Pengawasan, Penindakan

\begin{abstract}
globalization triggers all aspects of life, especially sources of information, climate, natural resources, technology, and the level of capability of each country, causing linkages between countries that make countries need each other. With the existence of a relationship between countries, an organization is formed that encourages each country to play an active role in the inter-national relations which have a goal of getting the benefits of becoming a developed country and not isolated. With Indonesia's natural wealth, strategic location, Indonesia is trying to attract as many tourists as possible, as well as trying to make the tourism sector one of the suppliers that can collect state income or foreign exchange in this country. This goal makes the government issue policies that demand development can increase the flow of human traffic from inside and outside the territory of Indonesia so that the government makes a provision based on its duties given to the immigration authorities for supervision and prosecution of foreigners who leave and enter Indonesian territory
\end{abstract}

Keywords: Globalization, Supervision, Enforcement

\section{Pendahuluan :}

\section{Latar Belakang}

Arus perkembangan zaman yang kian hari kian maju karena globalisasi memicu segala aspek kehidupan terutama sumber informasi, iklim, kekayaan alam, teknologi, serta tingkat kemampuan setiap negara menyebabkan ada keterkaitan antar negara 
yang menjadikan negara saling membutuhkan satu sama lain. Dengan adanya sebuah jalinan antar negara maka terbentuklah sebuah organisasi yang memacu setiap negara untuk berperan aktif dalam pergaulan antar bangsa yang memiliki sebuah tujuan untuk mendapatkan benefit agar menjadi negara maju dan tidak terisolasi. Dunia kini sudah cenderung kepada keterbukaan dan kerjasama yang saling menguntungkan. Pergaulan antar bangsa menjadi damai karena bangsa sekarang meninggalkan politik adu kekuatan, perang dingin antar bangsa adi daya telah mereda dan sebaliknya upaya saling membantu makin tampak. Setelah dari beberapa yang saya jelasakan diatas tentunya teknologi pun begitu pula, semakin maju terutama dibidang transportasi dan komunikasi. Jika kita melihat untuk setiap warga negara sudah dapat kita katakana bahwa tidak ada lagi sebuah negara yang terasingkan dan tidak terjamah oleh warga negara yang ada diseluruh dunia atau tidak terpengaruh oleh perkembangan yang terjadi disekitarnya. Semakin kedepan semakin maju kerjasama antar bangsa baik dari canggihnya penggunaan teknologi, membuat terjadinya peningkatan arus lalu lintas antar suatu negara. Indonesia merupakan negara berkembang tentunya Indonesia sendiri memerlukan bantuan dari negara maju baik berupa modal, teknologi dan tenaga ahli. Disisi lain, Indonesia juga memerlukan pasar di luar negeri terutama dalam pemasaran produk-produk dari migas maupun non migas.

Dengan kekayaan alam yang ada di Indonesia, lokasi yang strategis, Indonesia berusaha untuk menarik wisatawan sebanyak mungkin, serta berupaya juga menjadikan sector pariwisata menjadi salah satu pemasok yang dapat menghimpun pendapatan negara atau devisa pada negara ini. Tujuan tersebut menjadikan pemerintah mengeluarkan kebijakan yang tuntutan pembangunan dapat membuat trjadinya peningkatan arus lalu lintas manusia dari dalam serta ke luar wilayah negara Indonesia sehingga dari pihak pemerintah membuat sebuah ketetapan berdasarkan tugasnya yang diberikan pada pihak keimigrasian untuk pengawasan dan penindakan sesuai dengan bunyi pasal 1 Undang-undang Nomor 6 Tahun 2011 tentang keimigrasian yaitu "hal ihwal lalu lintas orang yang masuk atau keluar Wilayah Indonesia serta pengawasannya dalam rangka menjaga tegaknya kedaulatan negara".

Peningkatan arus migrasi ini menjadi sebuah hal yang akanberdampak positif dan negatif bagi sebuah negara. Dampak positifnya yaitu pertumbuhan ekonomi pada negara tersebut. Namun, jika terdapat dampak positif tentunya ada negatif yaitu munculnya tindak pidana keimigrasian misalnyapembajakan, penyelundupan, pencurian kekayaan alam, penjualan pasir, pencurian hak paten, pencemaran laut, pencucian uang (money laundering), pencurian ikan, kejahatan maya (cyber crime), pemalsuan dokumen dan perdagangan narkoba dan obat-obatan terlarang. Penanganan bermacam-macam ancaman diatas tentunya akan membutuhkan kemampuan teknologi dan ilmu pengetahuan sebagai cara untuk mengatasi kejahatan seperti kejahatan korporasi, kejahatan terorganisir, kejahatan perbankan, kejahatan pasar modal, kejahatan internet, kejahatan transportasi, kejahatan konsumen dan persaingan curang, kejahatan kartu kredit dan pemalsuan cek, kejahatan bidang asuransi, kejahatan dibidang kepailitan, kejahatan pencucian uang, kejahatan penggelapan pajak, kejahatan ekspor fiktif, kejahatan penimbunan barang kebutuhan rakyat dan kejahatan malpraktek profesi serta penyalahgunaan ijin tinggal keimigrasian. Kejahatan yang dapat kita lihat pada jaman sekarang ini mulai berkembang dari yang awalnya tidak terorganisasi menjadi terorganisasi (organized crime). Sebagai petugas keimigrasian kita harus dapat memaksimalkan dampak positif serta memininalkan dampak negative dari adanya 
arus migrasi atau lalu lintas dari wilayah negara satu ke wilayah negara lainnya dengan menegakkan hukum keimigrasian yang baik serta mampu untuk memberikan efek jera kepada pelaku tindak pidana keimigrasian sehingga akan dapat mengurangi dampak negative arus migrasi.

Berdasarkan hal tersebut, Imigrasimerupakansalah satu dari instansi pemerintah yang kegiatannya melakukan pengawasan serta pelayanan dalam melayani administrasi keimigrasian masyrakat, imigrasi melakukan pengawasan disini yaitu dengan melakukan pengawsan terhadap orang asing baik dengan keberadaan serta kegiatan orang asing. Untuk orang asing, layanan dan pengawasan pada bidang imigrasi mengikuti prinsip seleksi (kebijakan selektif). Orang asing yang bisa diberi visa masuk untuk Indonesia adalah, menurut prinsip ini, hanya orang asing yang dapat memberikan layanan untuk kepentingan rakyat, bangsa maupun Negara Kesatuan Republik Indonesia (NKRI), yang tidak membahayakan keamanan dan ketertiban dan tidak bersifat nasional serta anti pemerintah. Orang asing dipantau bukan hanya ketika tiba, tetapi selama mereka tinggal di wilayah Indonesia, hingga kegiatan mereka. Pengawasan imigrasi mencakup penegakan hukum imigrasi, baik hukum administrasi dan imigrasi. Penegakan Hukum Imigrasi membutuhkan pengawasan ketika ada penyimpangan. Langkah-langkah yang dimaksud dalam bidang imigrasi adalah peradilan dan non-yudisial tanpa melalui proses peradilan dalam bentuk file administrasi imigrasi.

Pengawasan orang asing bukan hanya dilakukan ketika mereka masuk tetapi selama mereka berada di wilayah Indonesia, termasuk juga kegiatannya. Pengawsan keimigrasian mecakup penegakan hukum. Penegakan yang diatur pada beberapa tahap proses peradilan, berlangsung dalam penyelidikan awal menurut ketentuan Undang-Undang Nomor 6 Tahun 2011 tentang imigrasi, yang dilakukan sejalan dengan prinsip dan prosedur hukum Kode Acara Pidana KUHAP pada Undang-undang Nomor 8 Tahun 1981 tentang KUHAP tanpa menjalani proses hukum dalam bentuk tindakan administrasi imigrasi, yang merupakan tindakan administratif dibidang imigrasi di luar proses pengadilan. Imigrasi merupakan kejahatan khusus, sehingga hukum formal dan hukum substantif berbeda dari hukum pidana umum.

Penegakan hukum keimigrasian membutuhkan tindak lanjut melalui suatu penindakan yang dilakukan oleh pejabat imigrasi dan beberapa penyidik yang telah mengikuti pelatihan penyidik apabila terdapat suatu penyimpangan. Penindakan yang dimaksud bidang keimigrasian adalah melalui tahapan peradilan umum (pro justisia) tanpa melalui proses peradilan berupa tindakan keimigrasian. Sehingga dalam penegakkan hukum keimigrasian Penyidik Pegawai Negeri Sipil dalam lingkungan Imigrasi telah dikenal dari sebelum berlakunya Undang-Undang Nomor 8 Tahun 1981 mengenai Kitab UndangUndang Hukum Acara Pidana. Karena sejak jaman colonial Belanda telah terdapat aturan perundang-undangan yang membuat undangundang pegawai di suatu instansi tertentu yang diberikan wewenang penyidik.

Meskipun diakui oleh UU Nomor 9 Tahun 1992 yang menentukan kewajibankewajiban dan batasan-batasan tertentu, Pengaturan tentang keimigrasian merupakan suatu hak serta wewenang Negara Kesatuan Republik Indonesia dan merupakan salah satu perwujudan dari kedaulatannya sebagai negara hukum yang berdasar pada Pancasila dan Undang-Undang Dasar 1945. akan tetapi pada implementasinya Penyidik Pegawai Negeri Sipil sebenarnya kurang terlihat keberadaanya. Hal sedemikian rupa dikarenakan terlalu dominan peran pejabat penyidik dari kepolisian dalam menangani suatu perkara dalam tindak pidana keimigrasian. Walalupun seacra teknis PPNS dianggap sebagai orang yang menguasai permasalahan tapi dalam pengambilan 
keputusan tetap berada ditangan penyidik Polri. Kewenangan yang bersifat setengahsetengah membuat penyidik pegawai negeri sipil kurang efisien melaksanakan tugas.

Investigasi melibatkan serangkaian langkah-langkah investigasi, sebagaimana didefinisikan pada Undang-Undang ini, dalam menemukan dan mengumpulkan bukti secara jelas mengidentifikasi pelanggaran yang dilakukan dan menemukan tersangka. untuk memastikan jika kejahatan telah dilakukan sesuai dengan UU 6 tahun 2011 tentang imigrasi. Para penyelidik harus terlebih dahulu mendapatkan atau mendapatkan bukti dan kemudian menjatuhkan tuduhan terhadap seseorang. Ini berarti bahwa fakta dan keadaan didasarkan pada informasi yang diyakini sebagai tindak pidana berdasarkan bukti dan bukan hanya kesimpulan. Keberhasilan persidangan pidana sangatlah berpedoman dari bukti pada kasus pidana imigrasi. Atas dasar UndangUndang Nomor 8 Tahun 1981 mengenai prosedur pidana berdasarkan Pasal 183, seorang hakim dapat menghukum seseorang hanya jika ia telah dihukum oleh setidaknya dua bukti yang sah bahwa suatu pelanggaran telah dilakukan dan terdakwa telah melakukannya. Pasal 183 jo 184 KUHAP juga membentuk dasar kepada seseorang penyidik dalam menentukan awal untuk bagaiamana memulai suatu penyidikan tindak pidana Keimigrasian $($ SPDP $=$ Surat Perintah Dimulainya Penyidikan), yang mesti dikerjakan secara cermat, teliti, cerdas, bertanggung jawab, berdasarkan Undangundang Nomor 6 tahun 2011 tentang Keimigrasian.

Undang-undang imigrasi tidak hanya memuat aturan imigrasi umum, tetapi juga ketentuan hukum pidana dan bukti berkaitan pada kejahatan keimigrasian. Ketentuan hukum pidana adalah pedoman petugas penegak hukum, baik otoritas imigrasi dan yudisial, dalam menyelidiki dan memutuskan masalah pidana berkaitan dengan imigrasi. Pengambilan bukti memainkan peran sangat berpengaruh dalam pemeriksaan proses pidana. Masalah pembuktian seringkali menghadirkan kesulitan bagi otoritas imigrasi sebagai otoritas imigrasi PPNS dan juga kantor kejaksaan umum sebagai kantor kejaksaan umum dan pengadilan untuk memeriksa dan memutuskan kasus. Ketentuan tentang bukti untuk pemeriksaan pelanggaran keimigrasian berdasarkan Pasal 108 UU Nomor 6 tahun 2011 yang berkaitan dengan imigrasi dalam bentuk:

1. Bukti berdasarkan hukum acara pidana;

2. Bukti lain dalam bentuk informasi yang diucapkan, ditransmisikan, diterima atau disimpan dalam bentuk elektronik maupun sejenisnya;

3. Pernyataan tertulis dari petugas imigrasi yang berwewenang.

Bukti yang tersedia saat ini sangatlah terbatas mengingat perubahan yang relatif cepat di dalam lingkungan. Untuk bukti deteksi kejahatan keimigrasian, dua bukti di luar KUHAP dapat digunakan untuk bukti tambahan pada prosedur pemeriksaan. Penggunaan dua buah bukti masih jarang untuk digunakan, sehingga tingkat efektivitas masih dianggap kurang. Walaupun bukti umumnya diperlukan hanya jika bukti lain tidak memenuhi batas bukti minimum yang ditetapkan pada Pasal 183 KUHAP. Menghindari atau setidaknya meminimalkan keputusan pengadilan, yang memberi keputusan bebas atau pembatalan hukuman terhadap pihak yang bersalah, pertimbangan yang cermat.

Secara khusus, dalam kasus kejahatan imigrasi, penilaian bukti pada saat pemeriksaan diharapkan. Perkembangan teknologi saat ini memudahkan orang dalam berkomunikasi tanpa batasan jarak maupun waktu, dan mempermudah para pengguna dalam berbagi informasi. Tetapi, tidak bisa dipungkiri jika kemajuan teknologi dalam tahap ini merupakan potensi besar untuk pengembangan berbagai bentuk kejahatan. Internet bisa menjadi media yang dapat memudahkan seseorang untuk melakukan kejahatan berdasarkan teknologi informasi (cybercrime). Informasi elektronik 
didapatkan jika terjadi tindak pidana yang bisa digunakan sebagai bukti pada penyelidikan tindak pidana.

Tri Fungsi Keimihrasian sedang ditunda dalam evolusinya karena memahami fungsi keamanan dan penegakan hukum adalah hal yang tidak dapat dipisahkan, disebabkan penerapan penuntutan imigrasi artinya sama dengan menciptakan kondisi keamanan yang kondusif atau mungkin sebaliknya, dan kondisi keamanan yang kondusif menjunjung tinggi dengan cara. Penegakan hukum otomatis untuk otoritas imigrasi harus dilakukan secara konsisten dan konsisten. Sementara fungsi baru untuk mempromosikan pembangunan adalah hal yang tidak dapat terpisahkan dari fungsi imigrasi lainnya.

\section{Rumusan Masalah}

Berdasarkan dari latar belakang yang telah dijelasakan diatas, maka masalah yang dapat kita buat didalam studi kasus ini yaitu : 1.Apa yang dimaksud dengan tindak pidana keimigrasian?

2.Apa saja Tugas dan Fungsi Penyidik Pegawai Negeri sipil imigrasi berdasarkan ketetapan aturannya?

\section{Tujuan Penelitian}

Tujuan dari penelitian ini guna mengetahuai apa itu tindak pidana keimigrasian dan perbuata seperti apa saja yang dapat dikenakan tindak pidana keimigrasian, serta guna mengetahui apa saja tugas dan fungsi PPNS imigrasi dan bagaimana PPNS imigrasi dalam menjalankan tugasnya yang berdasarkan pada peraturan yang ada.

\section{Metode Penelitian}

Pada penelitian ini menggunakan metode dengan pendekatan kualitatif yang dimana metode kualitatif ini sebagai metode ilmiah yang sering digunakan oleh beberapa peneliti pada bidang ilmu seperti social, dan juga pendidikan. Penelitian kualitatif digunakan untuk membangun pengetahuan melalui pemahaman dan penemuan. Pendekatan penelitian kualitatif merupakan suatu proses penelitian dan pemahaman yang berdasarkan pada metode menyelidik suatu fenomena social dan masalah manusia

\section{Pembahasan}

1. Pengertian Tindak Pidana Keimigrasian Segala tindakan yang melanggar ketentuan keimigrasian dalam bentuk pelanggaran pidana dan pelanggaran yang dapat dikenai sanksi pidana. Penegakan hukum imigrasi di wilayah Republik Indonesia, baik preventif dan represif, dilakukan antara lain dengan langkahlangkah yang konkrit. Imigrasi pada dasarnya bukan hanya kejahatan internasional dan transnasional dan dilakukan secara terorganisir, tetapi sangat berbahaya dan membahayakan masyarakat. Oleh karena itu, ancaman kriminal yang serius diperlukan untuk memberikan efek jera kepada alien yang melakukan pelanggaran. Imigrasi diatur oleh Undang-Undang Nomor 9 Tahun 1992 mengenai imigrasi, bersama dengan sanksi pidana yang dikenakan pada warga negara Indonesia dan asing.

Jenis-jenis undang-undang imigrasi Pasal 62 Undang-Undang Nomor 9 Tahun 1992 mengenai imigrasi mengatur klasifikasi kejahatan yang dapat dilakukan dalam konteks imigrasi, yang terdiri dari pelanggaran dan pelanggaran. Kejahatan didefinisikan suatu tindakan menyimpang yang melanggar hukum dan, dalam penglihatan masyarakatmenjijikkan. Tindakan yang tergolong pelanggaran pada klasifikasi pelanggaran keimigrasian yang ditetapkan oleh Undang-Undang ini mencakup, namun tidak terbatas pada, kegiatan di dalam atau di luar wilayah Indonesia tanpa inspeksi yang dikerjakan di kantor pemerintah.

Keimigrasian pada pemeriksaan data pribadi yang relevan sangat penting dalam konteks pemantauan kemungkinan hal-hal yang berbahaya bagi negara. Verifikasi juga menyangkut keakuratan data atau keaslian 
visa atau izin imigrasi, yang mana hal ini diatur oleh Pasal 49 Undang-Undang Nomor 9 tahun 1992 dengan hukuman 6 tahun dan hukuman maksimum Rp30.000.000 (tiga puluh juta Rupiah). Pada masalah pemalsuan atau penggunaan yang disengaja dari surat perjalanan palsu Republik Indonesia dan penyebarannya kepada orang lain yang tidak memenuhi syarat dalam pelanggaran berdasarkan Pasal 55 Undang-Undang Nomor 9 tahun 1992. Pasal 56 juga mengatur ancaman pidana terhadap pelanggar dalam memproduksi dan mencetak dokumen perjalanan Republik Indonesia tanpa hak dan melanggar hukum. Serta pada Pasal 59 hukum. Nomor 9 tahun 1992 untuk petugas imigrasi yang menyerahkan dokumen perjalanan Republik Indonesia pada orang yang diketahui tidak tersedia bagi mereka diancam hukuman maksimum tujuh tahun.

Orang asing yang masuk maupun tinggal di wilayah Indonesia juga tidak kebal terhadap ancaman kriminal jika orang tersebut melakukan pelanggaran sebagaimana didefinisikan dalam bagian "Ketentuan Pidana" Nomor 9 tahun 1992. Perbuatannya adalah:

1. Penyalahgunaan izin imigrasi atau melakukan kegiatan yang tidak sejalan dengan izin imigrasi yang diberi kepadanya dan dihukum dengan hukuman penjara tidak melebihi 5 tahun atau hukuman maksimum Rp. 25.000.000 (dua puluh lima juta) ini adalah Pasal 50. Ketentuan pidana pada artikel ini secara alternatif dalam bentuk penjara atau bisa diganti berupa denda.

2. Visa masuk telah kedaluwarsa dan tetap berada di Indonesia selama lebih dari 60 (enam puluh) hari setelah berakhirnya periode penjara untuk maksimum 5 (lima) hari atau hukuman maksimum Rp. 25.000.000 (dua puluh lima juta rupiah) sebagaimana dimaksud dalam Pasal 52, dengan ketentuan bahwa ketentuan hukum pidana dalam Pasal ini merujuk pada Pasal 45 (1) dan 51. Jika tidak ada izin imigrasi yang berlaku tidak lebih dari
60 (enam puluh) hari, maka akan dikenakan biaya. Pasal 51. Jika mereka tidak mau membayar beban, mereka tunduk pada Pasal 51. Jika keberadaan mereka tanpa izin masuk melebihi 60 (enam puluh) hati, mereka tidak akan dikenakan biaya, tetapi artikel ini akan dibebankan secara langsung (Moh Arif, 1997: 87).

3. Pasal 53: Orang asing yang secara ilegal berada di wilayah Indonesia atau telah diusir atau diusir dan yang secara ilegal hadir di wilayah Indonesia menghadapi hukuman penjara maksimum 6 (enam) atau denda maksimum Rp30.000.000 (tiga puluh juta Rupiah). Orang asing yang disebutkan pada artikel ini dikenal sebagai imigran gelap dan terdiri dari:

a. Masuk dan hadir secara ilegal di wilayah Indonesia, masuk tanpa izin bukan dengan inspeksi oleh petugas imigrasi dan keberadaan merekamasuk dan tinggal secara ilegal;

b. Entri resmi ke wilayah Indonesia, hilangnya dan kurangnya izin masuk lainnya telah berakhir.

Pelanggaran pidana yang tergolong dalam klasifikasi pelanggaran sebagai berikut:

1. Kesalahan penyajian identitas diri dan keluarga mereka, perubahan status sipil dan kebangsaan dan perubahan alamat; Tidak dapat memberikan dokumen perjalanan atau dokumen imigrasi saat diminta oleh pengawasan; dan jangan mendaftar jika Anda menghabiskan lebih dari 90 (sembilan puluh hari) di Indonesia. Menerapkan pelanggaran administrasi seperti:

a. Non-pembayaran lembur sepanjang tidak melebihi 60 (enam puluh) hari sejak tanggal penerbitan izin masuk;

b. Non-pembayaran biaya transportasi yang tidak memenuhi kewajibannya berdasarkan aturan yang berlaku; Diancam hukuman penjara maksimal satu (1) tahun atau denda maksimal 
Rp5.000.000, - (lima juta rupiah) berdasarkan Pasal 51 UndangUndang Nomor 9 Tahun 1992;

2. Pasal 60 memberi orang asing pilihan untuk menginap dan melaporkan pada pihak berwewenang dalam waktu 24 (dua puluh empat) jam mulai kedatangan orang asing, yang menghadapi hukuman penjara maksimum satu (satu) atau denda maksimum Rp. 5.000.000 (lima juta rupiah).

3. Berdasarkan Pasal 61, orang asing yang memiliki izin tinggal tapi tidak melapor ke Kepolisian Nasional dalam waktu 30 (tiga puluh) hari mulai tanggal orang yang bersangkutan menerima izin tinggal dapat dipenjara tidak lebih dari satu (satu) atau denda Rp 5.000.000 (lima juta Rupiah). Berdasarkan aturan yang terdapatpada artikel dalam bab tentang ketentuan hukum pidana. Berkenaan dengan imigrasi Nomor 9 tahun 1992, pengawasan orang asing tampaknya cukup ketat. Ini ditegakkan oleh tidak lain dari niat upaya penegakan hukum terhadap imigrasi.

2.Tugas dan Fungsi Penyidik Pegawai Negeri Sipil Keimigrasian

Pasal 105 UU No. 6 Tahun 2011, menyatakan bahwa Pejabat Pegawai Negeri Sipil (PPNS) Keimigrasian diberi wewenang sebagai penyidik tindak pidana keimigrasian yang dilaksanakan sesuai dengan ketentuan Undang-Undang ini. PPNS diberi wewenang khusus menjadi penyidik sebagaimana dimaksud dalam UU No. 8 Tahun 1981 untuk melakukan penyidikan tindak pidana keimigrasian. Sesuai ketentuan Pasal 107 UU No. 6 Tahun 2011 bahwa dalam melakukan penyidikan, PPNS Keimigrasian berkoordinasi dengan Penyidik Kepolisian Negara Republik Indonesia, bentuk koordinasi dan pengawasan tersebut dicantumkan dalam Pasal 107 ayat (1), ayat (2) dan ayat (3) Hukum Acara Pidana, yaitu: Pasal 107 ayat (1)

Untuk kepentingan penyidikan, Penyidik Kepolisian Republik Indonesia memberikan petunjuk kepada Penyidik Pegawai Negeri Sipil dan memberikan bantuan penyidikan yang diperlukan.

Pasal 107 ayat (2)

Penyidik Pegawai Negeri Sipil melaporkan kepada Penyidik Kepolisian Republik Indonesia tentang adanya suatu tindak pidana yang sedang disidik, jika dari penyidikan itu oleh Pegawai Negeri Sipil ditemukan bukti yang kuat untuk mengajukan tindak pidananya kepada penuntut uтum.

Pasal 107 ayat (3)

Penyidik Pegawai Negeri Sipil jika telah selesai melakukan penyidikan, hasil penyidikan tersebut harus diserahkan kepada penuntut umum melalui Penyidik Kepolisian Republik Indonesia.

Penyelidik petugas imigrasi memiliki wewenang berdasarkan hukum yang membentuk dasar hukum dan berada di bawah tugasnya untuk mengoordinasi dan mengawasi penyelidik Kepolisian Nasional. Langkah-langkah keimigrasian, termasuk 4 aspek kegiatan, yaitu:

1. Pemrosesan hasil pemantauan dan/atau investigasi. Penemuan tindakan melawan hukum yang dihasilkan dari pemantauan dan bukti investigasi diproses dan disortir sesuai dengan sifat dan sifat pelanggaran. menentukan tindakan imigrasi yang sesuai pada pelanggar hukum.

2. Investigasi dengan cara investigasi dari tersangka, sanksi dan bukti sebagai hasil pengawasan membuat laporan resmi. Sementara hasil investigasi dan kasuskasus di mana keputusan telah diambil dan yang final tidak perlu dipertimbangkan, hanya perlu mengidentifikasi mantan narapidana berdasarkan dokumen perjalanan. Surat atau dokumen lain dan keputusan hakim, sehingga mereka tidak salah saat menerapkan langkah-langkah imigrasi.

3. Penegakan Melakukan tindakan administratif pada orang yang tidak mematuhi aturan dan/atau terlibat dalam kegiatan yang mengganggu keselamatan 
serta ketertiban umum, yang terdiri sebagai berikut:

a) warga negara Indonesia dalam bentuk blokade, menolak masuk ke wilayah Indonesia meninggalkan, mencabut, serta hal-hal lain yang berkaitan dengan dokumen perjalanan Republik Indonesia;

b) Orang asing dalam bentuk penghalang, penolakan masuk dan keluar dari wilayah Indonesia, biaya, deportasi, karantina, pembatasan / pembatalan / perubahan izin tinggal, larangan untuk tinggal disatu tempat atau lebih, kebutuhan untuk tinggal di tempat tertentu untuk menghentikan tempat;

c) Orang yang bertanggung jawab untuk transportasi dalam bentuk: biaya pemulangan alien yang belum diberikan izin masuk, orang asing yang belum diberikan izin masuk, yang tetap dalam perjalanan atau yang terisolasi.

4. Penyelesaian dan penyerahan file adalah tugas akhir dari penyelidikan imigrasi. Hasil dari pemeriksaan para tersangka dan para ahli, yang kelengkapannya sesuai dengan unsur-unsur kejahatan imigrasi, berfungsi sebagai dasar untuk memeriksa penyelesaian dan pengarsipan file. Kegiatan pengarsipan terdiri dari:

a) CV Creation adalah kegiatan imigrasi PPNS yang dirancang untuk menghasilkan ringkasan dan kesimpulan berdasarkan hasil penyelidikan kejahatan imigrasi.

b) Kompilasi konten file. Dalam melakukan investigasi, PPNS bertanggung jawab secara hukum untuk melakukan investigasi sesuai dengan hukum dan peraturan yang berlaku, sementara tanggung jawab resmi bersifat hierarkis.

Dalam hal ini, Direktur Jenderal Imigrasi dapat memandu kegiatan investigasi selama implementasi, membimbing dan membantu dalam kejahatan imigrasi investigasi. Layanan Imigrasi PPNS harus berkoordinasi dengan lembaga pemerintah terkait Ketenagakerjaan, Kejaksaan Agung, dan bahkan dengan Kantor Luar Negeri, Kementerian Dalam Negeri, Kementerian Dalam Negeri, Departemen Pertahanan dan Keamanan, dan Kementerian dalam melaksanakan tanggung jawab pengawasannya. Badan Intelijen Negara (BIN) . Dalam penegakan hukum imigrasi, ada dua opsi untuk penyelesaian kejahatan imigrasi, yaitu imigrasi dan pro-yudisial. Pelanggaran dan kejahatan di bidang imigrasi harus dicegah dan dihilangkan dengan penuntutan di bidang imigrasi. Secara hukum, kejahatan keimigrasian adalah segala tindakan yang melanggar ketentuan imigrasi dalam bentuk kejahatan dan yang dikenakan sanksi pidana berdasarkan UU Nomor 6 tahun 2011, menetapkan ketentuan mengenai kejahatan imigrasi dalam bentuk kejahatan dan pelanggaran pidana Pelanggaran, khususnya pelanggaran keimigrasian, yang diatur oleh Pasal 113 hingga 136 UU Nomor 6 tahun 2011.

\section{Penutup \\ Kesimpulan}

Investigasi pelanggaran hukum keimigrasian oleh imigrasi PPNS didasarkan pada ketentuan dalam KUHAP, dengan bermacam pengecualian, yang secara khusus diatur dalam undang-undang imigrasi. Hasil penuntutan pelanggaran hukum imigrasi oleh Departemen Imigrasi (PPNS) Direktorat Jenderal Imigrasi menunjukkan bahwa sebagian besar pelaku pelanggaran imigrasi dikenai sanksi administratif oleh pejabat imigrasi. Pelaku pelanggaran hukum imigrasi diadili dan dihukum oleh pengadilan, jumlahnya sangat rendah. Pejabat imigrasi memiliki wewenang penuh dalam menentukan apakah seorang warga negara yang melakukan pelanggaran keimigrasian akan dihukum dalam bentuk tindakan administratif. Ketika menjatuhkan sanksi dalam bentuk tindakan administratif, pejabat imigrasi perlu untuk mempertimbangkan 
faktor sosial, budaya, ekonomi dan keamanan. Mempertimbangkan faktor-faktor ini, pejabat imigrasi menganggap lebih efektif dan efisien bahwa orang asing yang melanggar undang-undang imigrasi dikenai sanksi administratif, daripada dibawa ke pengadilan karena diadili. Untuk menghindari dampak diskriminatif pada penegakan hukum, hukuman dalam bentuk tindakan administratif harus didasarkan pada pertimbangan obyektif pejabat imigrasi. Petugas imigrasi juga harus memperhatikan peran penegakan hukum, yang seharusnya memiliki efek jera pada pelaku atau orang lain yang tidak melanggar aturan imigrasi.

\section{DAFTAR PUSTAKA}

Bahri, Imam, Suhaidi, Mahmul Siregar, and Mahmud Mulyadi. "PENGAWASAN KEIMIGRASIAN TERHADAP ORANG ASING DALAM RANGKA PENDEPORTASIAN DITINJAU DARI UNDANG-UNDANG NOMOR 6 TAHUN 2011 TENTANG KEIMIGRASIAN (STUDI DI KANTOR IMIGRASI KELAS I POLONIA MEDAN)." Journal of Chemical Information and Modeling 53, no. 9 (2013): 1689-1699.

Deshinta, Wafia Silvi. "Fungsi Pengawasan Keimigrasian Dalam Pengendalian Radikalisme Pasca Penerapan Kebijakan Bebaas Visa Kunjungan” (2017): 15-28.

Imigrasi, Direktorat Jenderal. "UndangUndang Nomor 9 Tahun 1992 Tentang Keimigrasian" (1992).

Indonesia, Presiden Republik, and Wawasan Nusantara. "Undang Undang No . 8 Tahun 1981 Tentang: Kitab Undang Undang Hukum Acara Pidana" 1951, no. 8 (1981).

Keimigrasian, Undang-undang. "Penyidikan Oleh Penyidik Pegawai Negeri Sipil
Direktorat Jenderal Imigrasi Dalam Rangka Penegakan Hukum Terhadap Pelanggaran Undang-Undang Keimigrasian” (2006).

Kementrian Hukum dan HAM. UndangUndang Nomor 6 Tahun 2011 Tentang Keimigrasian. Indonesia, 2011.

Mulyawan, Budy, and Kementerian Hukum. "Kekuatan Alat Bukti Informasi Elektronik Dalam Penyidikan Tindak Pidana Keimigrasian” (2018): 107-118.

Nugroho, Trisapto Agung. "Peran Intelijen Keimigrasian Dalam Rangka Antisipasi Terhadap Potensi Kerawanan Yang Ditimbulkan Oleh Orang Asing Di Wilayah Indonesia." Jurnal Ilmiah Kebijakan Hukum 12, no. 3 (2018): 275.

Setiawati, Desi. "Penegakan Hukum Terhadap Warga Negara Asing (WNA) Yang Melanggar Izin Tinggal (Overstay)." Pandecta: Research Law Journal 10, no. 1 (2015).

Syahrin, M Alvi. "Penerapan Wewenang Penyidik Pegawai Negeri Sipil Dalam Melakukan Penyidikan Tindak Pidana Keimigrasian" (2018): 25-48.

\section{"FUNGSIONALISASI HUKUM PIDANA DALAM MENANGGULANGI TINDAK PIDANA KEIMIGRASIAN DI WILAYAH DKI JAKARTA.Pdf," n.d.}

